\title{
Effect of Some Postharvest Treatments on Quality Attributes Of Sweet Pepper Fruits During Cold Storage
}

\author{
Shehata, S.A. ${ }^{1}$;Emam, M.S. ${ }^{2}$; El-Helaly, M.A. ${ }^{1}$ and Gad-ELrab, N.A. ${ }^{2}$ \\ ${ }^{1}$ Vegetable Corps Department, Faculty of Agriculture, Cairo University, Giza, Egypt. \\ ${ }^{2}$ Postharvest and Handling of Vegetable Crops Research Department. HorticultureResearchInstitute, \\ Agricultural Research Center, Giza, Egypt.
}

\begin{abstract}
This study was carried out on sweet pepper fruits (Monist F1 hybrid) harvested at 3/4 yellowing color stage obtained from private farm, at Ismailia Governorate, during 2010-2011 and 2011-2012 seasons to study the effect of active and passive modified atmosphere packaging (MAP),packaging in perforated polypropylene bags (Pppb),hydrogen peroxide $\left(\mathrm{H}_{2} \mathrm{O}_{2}\right)$ at $0.12 \%$ and vapor $\operatorname{gard}(\mathrm{VG})$ at $0.1 \%$ treatments compared with untreated fruits(control) on the quality maintenance of sweet pepper fruits during storage at $10^{\circ} \mathrm{C}$. All studied treatments reduced weight loss, decay, firmness loss and color changes compared with untreated control.

Sweet pepper fruits packed in sealed polypropylene bags (active or passive MAP) was the most effective treatment in reducing weight loss percentage as compared with the other treatments and untreated control. Hydrogen peroxide or Pppb rated good appearance after 21 days at $10^{\circ} \mathrm{C}$.On the otherhand, untreated fruits having poorest appearance at the end of storage at $10^{\circ} \mathrm{C}$.

No decay was observed in sweet pepper fruits exposed to active MAP during storage. Furthermore, it is also reduced weight loss, maintained fruits firmness and retarded the loss of TSS, ascorbic acid and carotenoids and gave good appearance for 28 days at $10^{\circ} \mathrm{C},(28$ days).

The results suggested that active MAP at $5 \% \mathrm{O} 2+10 \% \mathrm{CO} 2$ followed by $\mathrm{H}_{2} \mathrm{O}_{2}$ treatments were the promising technique for maintaining quality and extending storage period of sweet pepper fruits.
\end{abstract}

Keywords: sweet pepper, postharvest, storage period, modified atmosphere packaging,hydrogen peroxide,vapor gard.

\section{Introduction}

Sweet pepper (Capsicum апnиum, L.) is one of the most important vegetable crops in the world. It is one of the vegetables that have excellent nutritive value, higher content of ascorbic acid, This research was supported by development of Postharvest Treatments Project which required for human nutrient (Davey et al., 2000). Nevertheless, it is very perishable vegetable with a short shelf life and high susceptibility to fungal diseases (Hardenburget al., 1990). The main factors of quality degradation of sweet pepper during prolonged storage are decay development (Barkai-Golan,1981), shriveling associated with rapid water loss (Maalekuuet al., 2003), poor external appearance (Ceponiset al., 1987) and susceptibility to chilling injury, which limits storage to temperature below $7^{\circ} \mathrm{C}$ (Paull, 1990). Therefore, maintaining freshness of pepper fruits has been a challenge in keeping its postharvest quality such as reducing water loss, delaying softening and extending shelf life period (Gonzalez et al., 1999;Xieet al., 2004). Refrigeration $\left(8-10^{\circ} \mathrm{C}\right)$ is the major tool to maintain quality and controlling decay of peppers (Hardenburget al., 1986). On the other hand, without refrigeration peppers deteriorate in few days as a result of rapid aging and parasitic infections (Ceponiset al., 1987). In addition to refrigeration, modified atmosphere packaging (MAP) is commonly used to maintain the quality and improve the shelf life of sweet pepper fruits (Akbudak, 2008).
Moreover packaging and low temperature storage has been shown to increase shelf life by slowing the growth of spoilage organisms (Miller et al., 1986). The MAP of sweet pepper which elevated $\mathrm{CO}_{2}$ and reduced $\mathrm{O}_{2}$ levels has been shown to inhibit fruit respiration, delay ripening, decrease ethylene production, retarding softening, maintains color and extending shelf life of pepper fruits (Ben-Yehoshua et al., 1983; Gonzalez and Tiznado, 1993; Akbudak, 2008 ;Shehata et al., 2013).

Postharvest treatments, with hydrogen peroxide $\left(\mathrm{H}_{2} \mathrm{O}_{2}\right)$ have been proposed as alternative to chemical treatments. It is a compound allowed for use in organic crop production according to National Organic Program (NOP, 2003). The use of $\mathrm{H}_{2} \mathrm{O}_{2}$ for disinfecting of fruits and vegetables appeared to reduce microbial populations on fresh products and extend the shelf life without leaving significant residues or causing loss of quality (Sapers and Simmons, 1998; Saperset al., 2001). In this concern, Bayoumi (2008) found that the use of $\mathrm{H}_{2} \mathrm{O}_{2}$ in postharvest treatments have a good potential strategy to improve the postharvest quality, extend shelf life period and maintained some nutritional quality as well as inhibiting decay development of peppers.

Waxy compounds have been applied widely in fruits and vegetables to prevent moisture losses, such as Vapor Gard (VG). In this concern, Shabana et al. (1985) found that date fruits treated with V.G. were superior in keeping quality and reduced the percentage of the defected and shrinked fruits when 
compared with untreated fruits. Also, Collie Graddicket al. (1986) stated that blueberry fruits dipped in V.G. at $2 \%$ for $10 \mathrm{~min}$ maintained their fresh appearance and marketable qualities when compared with untreated fruits.

The objective of this present work was to determine the potential benefits of modified atmosphere packaging, $\mathrm{H}_{2} \mathrm{O}_{2}$ and Vapor Gard treatments on the quality maintenance of sweet pepper fruits during storage at $10^{\circ} \mathrm{C}$ and shelf life conditions at $20^{\circ} \mathrm{C}$.

\section{Material and methods}

Seeds of sweet pepper (Capsicum annuиm, L.) Monist F1 hybrid were sown in the nursery on $11^{\text {th }}$ and $13^{\text {th }}$ of September in 2010 and 2011 seasons, respectively, and the seedling were transplanted on $25^{\text {th }}$ of October in both seasons, in green house conditions at Fayed district, Ismailia Governorate.

Sweet pepper fruits were harvested at 3/4 yellowing color stage on February $27^{\text {th }}$ and $29^{\text {th }}$ in 2011 and 2012 seasons, respectively, then transported to the laboratory of Handling of Vegetable Crops Research Department, Giza Governorate, uniform size each fruit about $280 \pm 10 \mathrm{~g}$. and color, all fruit has short calyx ( $1 \mathrm{~cm}$ long).Sound and healthy fruits free from each blemishes were selected to postharvest treatments experiments as follow:

1- Packaging in sealed polypropylene bags $(40 \mu$ thickness, $20 \times 30 \mathrm{~cm}$ size), then flushed with a gas mixture at $5 \% \mathrm{O}_{2}+10 \% \mathrm{CO}_{2}$ (active MAP). T1

2- Packaging in sealed polypropylene bags $(40 \mu$ thickness, $20 \times 30 \mathrm{~cm}$ size), (passive MAP). T2

3- Packaging in perforated polypropylene bags $(\mathrm{Pppb}),(40 \mu$ thickness, $20 \times 30 \mathrm{~cm}$ size with 4 holes (each $5 \mathrm{~mm}$ in diameter).T3

4- Dipping in solution of Hydrogen peroxide $\left(\mathrm{H}_{2} \mathrm{O}_{2}\right)$ at $0.12 \%$ for $30 \mathrm{~min}$. T4

5- Dipping in solution of Vapor Gard (VG) at $0.1 \%$ for $3 \mathrm{~min}$. T5

6- Untreated fruits (Control). T6

Twelve replicates were prepared from each treatment. Each replicate consisted of 3 fruits; and then placed in carton box. The samples were taken as random in 3 replicates and the samples were arranged in a complete randomized design and stored at $10^{\circ} \mathrm{C}$ and $90-95 \%$ relative humidity for 28 days. The treatments were examined immediately after harvest and every 7 days for the following properties:

1. Weight loss percentage.

2. General appearance was measured on scale of $9=$ excellent, $7=$ good, $5=$ fair, $3=$ poor, 1 =unsalable and fruits rating (5) or below were considered un marketable.

3. Decay was measured on scale of $1=$ non, $2=$ slight, $3=$ moderate, $4=$ sever, $5=$ extreme.
4. Firmness $\left(\mathrm{kg} / \mathrm{cm}^{2}\right)$ it was measured by a hand pressure tester (Italian model) expressed in $\mathrm{kg}$ / $\mathrm{cm}^{2}$ (Abbott, 1999).

5. Total soluble solids percentages (T.S.S), determined by using referactometer as described in A.O.A.C. (1990).

6. Ascorbic acid content $(\mathrm{mg} / 100 \mathrm{~g}$ fruit fresh weight), determined by titration method using 2.6 dichloro-phenole-end-phenole as described in A.O.A.C. (1990).

7. Total carotenoids content $(\mathrm{mg} / 100 \mathrm{~g}$ fresh weight) determined according to (A.O.A.C., 1990).

All the data were subjected tothe statistical analysis according to the method described by Snedecor and Cochran (1980).

\section{Results and disicussion}

\section{Weight loss}

Data in Table1 show that, weight loss percentage of sweet pepper fruits was increased considerably and consistently with the prolongation of storage period. These results were agreement with those obtained by Akbudak (2008). Normally, the weight loss occurs during fruit storage due to its respiratory processes, the transference of humidity and other senescence related metabolic processes during storage (Neillet al., 2002).

Concerning the effect of postharvest treatments on weight loss percentage, data reveal that there were significant differences between treatments in weight loss percentage during storage.However, all treatments retained their weight during storage as compared with the control (untreated fruits). Moreover, sweet pepper fruits packed in active MAP at $5 \% \mathrm{O}_{2}+10 \% \mathrm{CO}_{2}$ or passive MAPresulted in prominent reduction in weight loss percentage with non-significant differences between them. These results were agreement with those obtained by Nyanjageet al. (2005). In this respect, the highest values of weight loss percent were recorded with untreated fruits (control). This result was true in the two seasons of study.

Lowest weight loss from active or passive MAP is due to the confinement of moisture around the product by polypropylene bags. This increases the relative humidity and reduces vapor pressure deficit and transpiration. In addition, packaging creates a modified atmosphere with higher concentration of carbon dioxide and reduced oxygen around the product which slows down the metabolic processes and transpiration (Thompson, 1996), which diminished the weight loss during storage (Wang and Qi, 1997). Also, MAP reduced the water loss by minimizing the contact of fruits with the surrounding air or by inhibiting the diffusion of water vapor with permeability of vapors of the films (Akbudak, 2008). The highest weight loss observed in untreated fruits throughout the storage period can be attributed to air movement, which tends to sweep away the unstirred 
layer of air (at aquibrium vapor pressure with the tissues) adjacent to the surface of the product, thus increasing the vapor pressure deficit (Wills et al, 1998).

Hydrogen peroxide $\left(\mathrm{H}_{2} \mathrm{O}_{2}\right)$ and Vapor gard treatments significantly reduced fresh weight loss of pepper fruits as compared with untreated fruits (control) during storage, this agreement with the results obtained by Du et al. (2007) for $\mathrm{H}_{2} \mathrm{O}_{2}$ and Shabanaet al. (1985) for Vapor gard.The reduction of weight loss percentage by using $\mathrm{H}_{2} \mathrm{O}_{2}$ may be attributed to reducing the respiration process rates during postharvest storage ( $\mathrm{Du}$ et al., 2007; Bayoumi, 2008). In this concern, Neill et al. (2002) and Desikanet al. (2004) demonstrated that absicic acid (ABA) induced stomatal closure of guard cells in Arabidopsis and it requires $\mathrm{H}_{2} \mathrm{O}_{2}$ to induced stomatal closure.

The favorable effect of Vapor gard treatment in reduction of weight loss may be due to the formation of thin layer covering the fruits which prevent moisture losses and also reduce gas exchange and subsequently inhibit metabolic activities (Shabanaet al. 1985).

As for the interaction between the used postharvest treatments and storage period, data in Table1 show that sweet pepper fruits exposed to active or passive MAP had the lowest weight loss percentage during all storage period. Studies have been shown that MAP has been beneficial for sweet pepper fruits (Nyanjageet al. 2005). These results were true in the two seasons.

Table 1. Effect of some postharvest treatments on weight loss (\%) of sweet pepperfruits during storage at $10^{\circ} \mathrm{C}$ in 2010 - 2011 and 2011- 2012 seasons.

\begin{tabular}{|c|c|c|c|c|c|c|c|c|c|c|c|c|}
\hline \multirow{3}{*}{ Treatments } & \multicolumn{6}{|c|}{ 2010/2011 seasons } & \multicolumn{6}{|c|}{ 2011/2012 seasons } \\
\hline & \multicolumn{5}{|c|}{ Storage period in days } & \multirow{2}{*}{ Mean } & \multicolumn{5}{|c|}{ Storage period in days } & \multirow{2}{*}{ Mean } \\
\hline & 0 & 7 & 14 & 21 & 28 & & 0 & 7 & 14 & 21 & 28 & \\
\hline Active MAP & 0.00 & 0.04 & 0.08 & 0.13 & 0.17 & 0.08 & 0.00 & 0.07 & 0.12 & 0.16 & 0.20 & 0.11 \\
\hline Passive MAP & 0.00 & 0.06 & 0.12 & 0.16 & 0.19 & 0.11 & 0.00 & 0.05 & 0.10 & 0.17 & 0.21 & 0.10 \\
\hline Pppb & 0.00 & 0.39 & 1.89 & 2.45 & 3.72 & 1.69 & 0.00 & 0.73 & 1.76 & 2.47 & 3.53 & 1.70 \\
\hline Hydrogen peroxide & 0.00 & 0.93 & 2.11 & 2.85 & 4.44 & 2.07 & 0.00 & 0.80 & 2.11 & 2.94 & 4.92 & 2.16 \\
\hline Vapor gard & 0.00 & 1.07 & 2.68 & 3.69 & 4.91 & 2.47 & 0.00 & 1.00 & 2.55 & 3.68 & 5.27 & 2.50 \\
\hline Control & 0.00 & 2.12 & 3.78 & 4.87 & 6.17 & 3.39 & 0.00 & 2.77 & 5.02 & 6.45 & 8.39 & 4.52 \\
\hline Mean & 0.00 & 0.77 & 1.78 & 2.36 & 3.27 & & 0.00 & 0.90 & 1.94 & 2.64 & 3.75 & \\
\hline \multicolumn{13}{|l|}{ L.S.D. at $5 \%$} \\
\hline Treatments $(\mathbf{T})$ & \multicolumn{5}{|c|}{0.11} & \multicolumn{7}{|c|}{0.18} \\
\hline Storage period (S) & \multicolumn{5}{|c|}{0.10} & \multicolumn{7}{|c|}{0.16} \\
\hline $\mathbf{T} \times \mathbf{S}$ & \multicolumn{5}{|c|}{0.24} & \multicolumn{7}{|c|}{0.40} \\
\hline
\end{tabular}

\section{General appearance (GA)}

Data in Table2 show that, general appearance of sweet pepper fruits decreased with the prolongation of storage at $10^{\circ} \mathrm{Cin}$ both seasons. Similar results were reported by (Gonzalez-Aguilar et al., 1999). The decrease of GA during storage period might be due to shriveling, wilting, color change and decay (Banaras et al., 2005).

Significant differences in appearance were found between postharvest treatments on pepper fruits during storage. All treatments were better than the control, however, sweet pepper stored in active MAP at $5 \% \mathrm{O}_{2}+10 \% \mathrm{CO}_{2}$ orPppb and $\mathrm{H}_{2} \mathrm{O}_{2}$ was the most effective treatments for maintained general appearance during storage, this agreement with the results obtained by Akbudak, (2008) for MAP and Bayoumi, (2008) for $\mathrm{H}_{2} \mathrm{O}_{2}$. Previous studies showed that MAP delayed senescence of pepper (Gonzalez and Tiznado, 1993). MAP made a significant contribution on extending the postharvest longevity of pepper fruits having a high rate of postharvest water loss (Lownds and Bosland, 1988). Water saturated atmosphere within the packages controlled water loss due to transpiration delayed senescence in the absence of water stress and thereby extended postharvest longevity of fruits (Nawaet al., 2001).

The keeping quality of GA was improved by using $\mathrm{H}_{2} \mathrm{O}_{2}$ attributed to the effect of $\mathrm{H}_{2} \mathrm{O}_{2}$ on the reduction of weight loss and rot rate of pepper fruits (Bayoumi, 2008). $\mathrm{H}_{2} \mathrm{O}_{2}$ treatments have beneficial effects on fruit physiology such as delaying ripening of tomato by the increasing antioxidants content in fruits (Saltveit and Sharaf, 1992). In the same time, ethylene production by fruits can be reduced by $\mathrm{H}_{2} \mathrm{O}_{2}$ and this reduction keeps the appearance of fruits in the best condition.

The interaction between postharvest treatments and storage period revealed that sweet pepper fruits packed in polypropylene film and exposed to active MAP at $5 \% \mathrm{O}_{2}+10 \% \mathrm{CO}_{2}$ showed the best appearance, it does not exhibit any changes in their appearance till the 21 days at $10^{\circ} \mathrm{C}$ and gave good appearance at the end of storage. Meanwhile using $\mathrm{H}_{2} \mathrm{O}_{2}$ or $\mathrm{Pppb}$ rated good appearance till 21 days at $10^{\circ} \mathrm{C}$. On the other hand, untreated fruits (control) having the poorest appearance at the end of storage. These results were true in both seasons. 
Table 2. Effect of some postharvest treatments on general appearance (score) of sweet pepper fruits during storage at $10^{\circ} \mathrm{C}$ in $2010-2011$ and $2011-2012$ seasons.

\begin{tabular}{|c|c|c|c|c|c|c|c|c|c|c|c|c|}
\hline \multirow{3}{*}{ Treatments } & \multicolumn{6}{|c|}{ 2010/2011 seasons } & \multicolumn{6}{|c|}{$2011 / 2012$ seasons } \\
\hline & \multicolumn{5}{|c|}{ Storage period in days } & \multirow{2}{*}{ Mean } & \multicolumn{5}{|c|}{ Storage period in days } & \multirow{2}{*}{ Mean } \\
\hline & 0 & 7 & 14 & 21 & 28 & & 0 & 7 & 14 & 21 & 28 & \\
\hline Active MAP & 9.00 & 9.00 & 9.00 & 9.00 & 8.33 & 8.87 & 9.00 & 9.00 & 9.00 & 9.00 & 7.67 & 8.73 \\
\hline Passive MAP & 9.00 & 9.00 & 8.33 & 7.67 & 5.00 & 7.80 & 9.00 & 9.00 & 8.33 & 7.67 & 4.33 & 7.67 \\
\hline Pppb & 9.00 & 9.00 & 9.00 & 9.00 & 7.67 & 8.73 & 9.00 & 9.00 & 9.00 & 8.33 & 7.00 & 8.47 \\
\hline Hydrogen peroxide & 9.00 & 9.00 & 9.00 & 8.33 & 7.00 & 8.47 & 9.00 & 9.00 & 9.00 & 7.67 & 7.00 & 8.33 \\
\hline Vapor gard & 9.00 & 9.00 & 7.67 & 6.33 & 5.00 & 7.40 & 9.00 & 9.00 & 7.67 & 5.67 & 4.33 & 7.13 \\
\hline Control & 9.00 & 7.67 & 6.33 & 3.67 & 1.00 & 5.53 & 9.00 & 7.67 & 5.67 & 3.00 & 1.00 & 5.27 \\
\hline Mean & 9.00 & 8.78 & 8.22 & 7.33 & 5.67 & & 9.00 & 8.78 & 8.11 & 6.89 & 5.22 & \\
\hline \multicolumn{13}{|l|}{ L.S.D. at 5\% } \\
\hline Treatments (T) & \multicolumn{5}{|c|}{0.49} & \multicolumn{7}{|c|}{0.51} \\
\hline Storage period $(S)$ & \multicolumn{5}{|c|}{0.44} & \multicolumn{7}{|c|}{0.47} \\
\hline $\mathbf{T} \times \mathbf{S}$ & \multicolumn{5}{|c|}{1.09} & \multicolumn{7}{|c|}{1.14} \\
\hline
\end{tabular}

\section{Decay}

Data in Table3 showthat, there were significant increases in decay score with the prolongation of storage period. This finding may be due to the continuous chemical and biochemical changes in the fruits such as transformation of complex compounds to it simple forms that more liable to fungal infection (Wills et al., 1998). These results are similar to those obtained by Gonzalez-Aguilar et al.(1999). However, all postharvest treatments were much better in reducing decay and thus longer storage periods were gained.Sweet pepper fruit packed in active MAP was the most effective treatments on decay incidence during all storage period. Similar results were obtained by Gonzalez-Aguilar et al. (2004) who found that decay development of fresh-cut pepper stored at $5^{\circ} \mathrm{C}$ was retarded at high $\mathrm{CO}_{2} \mathrm{MAP}$. The decayed fruits started to be shown after 14 days of storage at $10^{\circ} \mathrm{C}$ for the untreated control, while, no decay was observed in fruits treated with active MAP at $5 \% \mathrm{O}_{2}+10 \% \mathrm{CO}_{2}, \mathrm{H}_{2} \mathrm{O}_{2}$ and Pppbtreatments during storage. Passive MAPwas effective up to 21 days at $10^{\circ} \mathrm{C}$. These fruits were scored with slight symptoms of decay after 28 days of storage, whereas untreated control showed severe decay symptoms at the end of storagein both seasons. Vapor gard treatment was less effective in reducing the decay symptoms.

Bayomi(2008) found that $\mathrm{H}_{2} \mathrm{O}_{2}$ treatment was highly decreased the extension of rot in pepper fruits. The reduction of decay by using $\mathrm{H}_{2} \mathrm{O}_{2}$ treatment may be attributed to that $\mathrm{H}_{2} \mathrm{O}_{2}$ as a reactive oxygen species (ROS) play important and manifold role in plant disease resistance to infection with pathogens.

In postharvest application, Simmons et al. (1997) stated that $\mathrm{H}_{2} \mathrm{O}_{2}$ treatment have been shown to decrease microbial loads of plums. Moreover, (Ukukuet al.2005) found that washing with $\mathrm{H}_{2} \mathrm{O}_{2}$ solution can markedly reduce the human pathogens.

The highest decay observed at the end of storage with passive MAP may be due to high relative humidity and water condensation around the product, which promote the development of postharvest decay (Coates et al. 1995).

The favorable effect of Pppb could be attributed to the continuous ventilation, less moisturecondensation and suppression of off-flavor development (Abd El-Rahman,1990). Also, Conesaetal.2007 found that MAP of pepper was avoid fermentation and inhibit growth of spoilage microorganisms. Moreover, (Jobling, 2001; Lee et al., 2006a and Lee et al., 2006b) stated that elevated $\mathrm{CO}_{2}$ levels can reduce the products sensitivity to $\mathrm{C}_{2} \mathrm{H}_{4}$; it can also slow the growth of many of the postharvest fungi that cause rots.

The interaction between the used treatments and storage period was non-significant between all treatments and storage period until 14 days and significant during the last period in both seasons. Active MAP, $\mathrm{H}_{2} \mathrm{O}_{2}$ and packaging in perforated polypropylene bag were the best treatments to minimizing decay score as the interaction with storage period.

\section{Fruit firmness}

Date in Table4 show that there was a significant reduction in fruit firmness by the prolongation of storage period in both seasons. Similar results were reported by Falliket al.(1999). The decline in fruit firmness may be due to the gradually breakdown of proto-pectin to lower molecular fractions which are more soluble in water and this was directly correlated with the rate of softening of the fruits (Wills et al., 1998).

Concerning the effect of postharvest treatments on fruit firmness during storage, data revealed that various applied treatments had significantly greater fruit firmness as compared with the untreated control. However, sweet pepper fruits packed in sealed polypropylene bags (active or passive MAP) or packed in perforatedpolypropylene bagswere the most effective treatment in reducing the loss of firmness with non-significant differences between them during storage at $10^{\circ} \mathrm{C}$, followed by $\mathrm{H}_{2} \mathrm{O}_{2}$ treatment. Vapor gard treatment was less 
effective in reducing firmness loss during storage as compared with the other treatments. These findings agreewith (Ben-Yahoshuaet al., 1983; GonzalezAguilar et al., 1999) who found that the main benefit of film packaging of peppers was the reduction in fruit water and firmness loss. Results of firmness showed similarities to weight loss which had strong relationship between firmness and weight loss in bell pepper was reported by Lurie et al. (1986).

Vapor gard is an anti-transpirant which forms a coating on the fruit and prevents evaporative water loss thus retaining fruit turgidity Le Lagadec and Moruda (2002), also Vapor gard inhibits the increase in polygalacturonase (the enzyme responsible) levels for pectin breakdown in ripening fruits (Lazanet al., 1990).

The interaction between postharvest treatments and storage period was significant in the two seasons. Sweet pepper fruits packed in sealed polypropylene bags with active MAP at $5 \% \mathrm{O}_{2}+10 \% \mathrm{CO}_{2}$ had the highest value of fruit firmness during all storage period.

Table 3. Effect of some postharvest treatments on decay (score) of sweet pepper fruits during storage at $10^{\circ} \mathrm{C}$ in 2010 - 2011 and $2011-2012$ seasons.

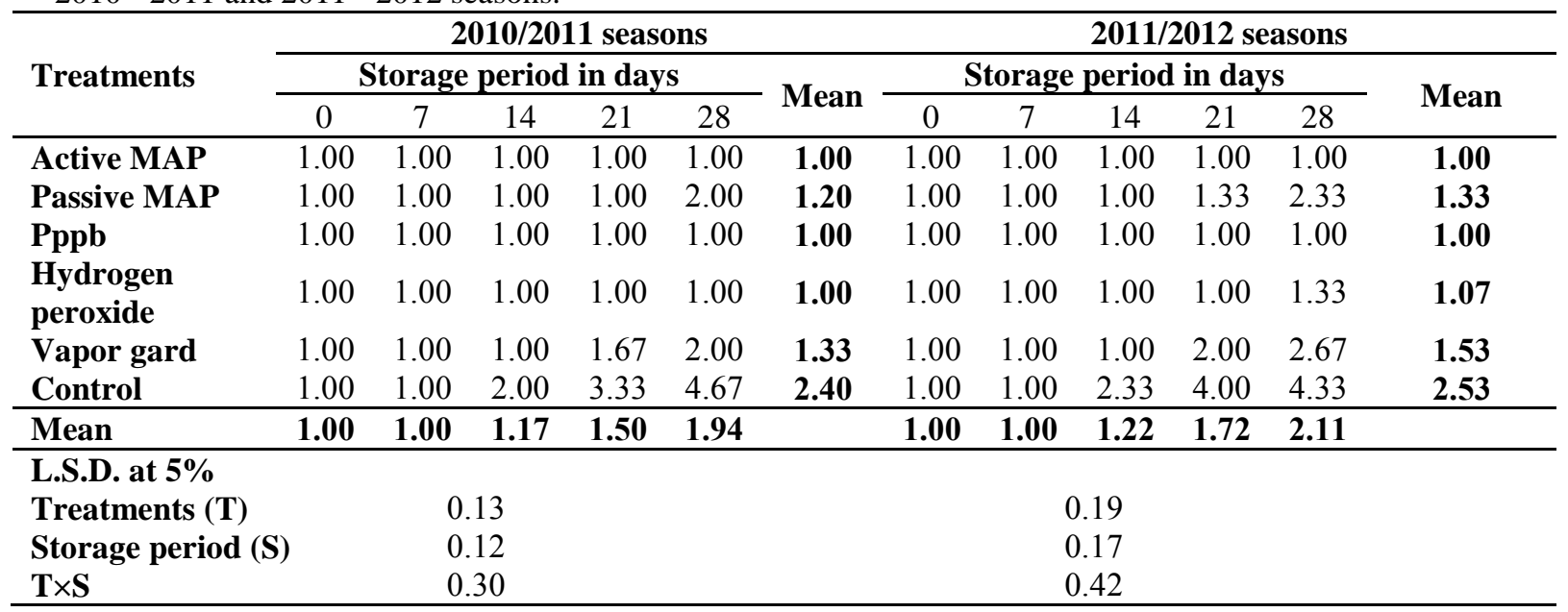

Table 4. Effect of some postharvest treatments on firmness $\left(\mathrm{kg} / \mathrm{cm}^{2}\right)$ of sweet pepper fruits during storage at $10^{\circ} \mathrm{C}$ in $2010-2011$ and $2011-2012$ seasons.

\begin{tabular}{|c|c|c|c|c|c|c|c|c|c|c|c|c|}
\hline \multirow{3}{*}{ Treatments } & \multicolumn{6}{|c|}{ 2010/2011 seasons } & \multicolumn{6}{|c|}{ 2011/2012 seasons } \\
\hline & \multicolumn{5}{|c|}{ Storage period in days } & \multirow{2}{*}{ Mean } & \multicolumn{5}{|c|}{ Storage period in days } & \multirow{2}{*}{ Mean } \\
\hline & 0 & 7 & 14 & 21 & 28 & & 0 & 7 & 14 & 21 & 28 & \\
\hline Active MAP & 220.00 & 218.33 & 216.67 & 213.33 & 210.00 & 215.67 & 218.33 & 215.00 & 213.33 & 210.00 & 203.33 & 212.00 \\
\hline $\begin{array}{l}\text { Passive } \\
\text { MAP }\end{array}$ & 220.00 & 216.67 & 213.33 & 210.00 & 207.00 & 213.40 & 218.33 & 213.33 & 210.00 & 206.67 & 201.67 & 210.00 \\
\hline Pppb & 220.00 & 213.33 & 210.00 & 206.67 & 201.67 & 210.33 & 218.33 & 211.67 & 208.33 & 201.67 & 193.33 & 206.67 \\
\hline $\begin{array}{l}\text { Hydrogen } \\
\text { peroxide }\end{array}$ & 220.00 & 210.00 & 205.00 & 200.00 & 195.00 & 206.00 & 218.33 & 208.33 & 201.67 & 198.33 & 190.00 & 203.33 \\
\hline Vapor gard & 220.00 & 210.00 & 199.00 & 192.33 & 180.00 & 200.27 & 218.33 & 206.67 & 198.33 & 188.33 & 178.33 & 198.00 \\
\hline Control & 220.00 & 200.00 & 190.00 & 182.33 & 170.00 & 192.47 & 218.33 & 201.67 & 188.33 & 181.67 & 166.67 & 191.33 \\
\hline Mean & 220.00 & 211.39 & 205.67 & 200.78 & 193.94 & & 218.33 & 209.44 & 203.33 & 197.78 & 188.89 & \\
\hline \multicolumn{13}{|l|}{ L.S.D. at $5 \%$} \\
\hline \multicolumn{3}{|l|}{ Treatments (T) } & \multicolumn{3}{|l|}{5.44} & & \multicolumn{6}{|c|}{7.14} \\
\hline \multicolumn{2}{|c|}{ Storage period (S) } & \multicolumn{4}{|c|}{4.97} & & \multicolumn{6}{|c|}{6.52} \\
\hline \multicolumn{2}{|c|}{$\mathrm{T} \times \mathrm{S}$} & \multicolumn{4}{|c|}{12.17} & & \multicolumn{6}{|c|}{15.97} \\
\hline
\end{tabular}

\section{Total soluble solids}

Data in Table5 demonstrate that total soluble solids (T.S.S) of sweet pepper fruits were significantly increased at the beginning of storage and then decreased with the prolongation of the storage period. Similar results were obtained by ElSheikh et al. (1997). The increase in T.S.S in the first period might owe much to the higher rate of moisture loss through transpiration. However, the reduction in T.S.S during the last period of storage might owe much to the higher rate of sugar loss through respiration than water loss through transpiration (Wills et al., 1998).

Concerning the effect of postharvest treatments on T.S.S, data revealed that there were significant differences between treatments in T.S.S percentages during storage, however, in general, sweet pepper fruits packed in active MAP at $5 \% \mathrm{O}_{2}+10 \% \mathrm{CO}_{2}$ and Pppb and dipping in $\mathrm{H}_{2} \mathrm{O}_{2}$ were significantly higher in fruit total soluble solids than other treatments. The lowest values of T.S.S \% were resulted in untreated fruits (control) in both seasons. Similar results were obtained by Akbudak (2008) who found that in 
pepper, MAP slowed down the changes in T.S.S values, and in this way, T.S.S changes in plastic material treated were suppressed, thus the ripening of fruits was inhibited.

For the effect of $\mathrm{H}_{2} \mathrm{O}_{2}$ treatment similar results were obtained by Penget al. (2003) who found that $\mathrm{H}_{2} \mathrm{O}_{2}$ treatment tended to maintain T.S.S values significantly better than the control. These treatments had superior positive effects, which might be at least partially attributed to this inhibition of phenolic metabolism.

The interaction between postharvest treatments and storage period was significant in the two seasons. After 28 days of storage at $10^{\circ} \mathrm{C}$, sweet pepper fruits packed in active MAP at $5 \% \mathrm{O}_{2}+10 \% \mathrm{CO}_{2}$ or fruits treated with $\mathrm{H}_{2} \mathrm{O}_{2}$ had the highest values of T.S.S \% with non-significant differences between them.

Table 5. Effect of some postharvest treatments on total soluble solids (\%) of sweet pepper fruits during storage at $10^{\circ} \mathrm{C}$ in $2010-2011$ and $2011-2012$ seasons.

\begin{tabular}{|c|c|c|c|c|c|c|c|c|c|c|c|c|}
\hline \multirow{3}{*}{ Treatments } & \multicolumn{6}{|c|}{ 2010/2011 seasons } & \multicolumn{6}{|c|}{ 2011/2012 seasons } \\
\hline & \multicolumn{5}{|c|}{ Storage period in days } & \multirow{2}{*}{ Mean } & \multicolumn{5}{|c|}{ Storage period in days } & \multirow{2}{*}{ Mean } \\
\hline & 0 & 7 & 14 & 21 & 28 & & 0 & 7 & 14 & 21 & 28 & \\
\hline Active MAP & 7.83 & 8.07 & 8.13 & 8.17 & 8.00 & 8.04 & 7.70 & 8.07 & 8.20 & 8.13 & 7.93 & 8.01 \\
\hline Passive MAP & 7.83 & 8.03 & 8.10 & 7.83 & 7.57 & 7.87 & 7.70 & 7.90 & 8.13 & 7.90 & 7.50 & 7.83 \\
\hline Pppb & 7.83 & 8.07 & 8.20 & 8.07 & 7.83 & 8.00 & 7.70 & 8.03 & 8.20 & 8.00 & 7.87 & 7.96 \\
\hline Hydrogen peroxide & 7.83 & 8.00 & 8.10 & 8.13 & 8.00 & 8.01 & 7.70 & 8.00 & 8.20 & 8.10 & 7.97 & 7.99 \\
\hline Vapor gard & 7.83 & 7.90 & 8.00 & 7.87 & 7.23 & 7.77 & 7.70 & 7.90 & 8.00 & 7.80 & 7.30 & 7.74 \\
\hline Control & 7.83 & 8.00 & 8.20 & 7.53 & 6.93 & 7.70 & 7.70 & 8.10 & 8.23 & 7.17 & 6.87 & 7.61 \\
\hline Mean & 7.83 & 8.01 & 8.12 & 7.93 & 7.59 & & 7.70 & 8.00 & 8.16 & 7.85 & 7.57 & \\
\hline \multicolumn{13}{|l|}{ L.S.D. at $5 \%$} \\
\hline Treatments (T) & \multicolumn{5}{|c|}{0.15} & \multicolumn{7}{|c|}{0.13} \\
\hline Storage period (S) & \multicolumn{5}{|c|}{0.14} & \multicolumn{7}{|c|}{0.12} \\
\hline $\mathbf{T} \times \mathbf{S}$ & \multicolumn{5}{|c|}{0.35} & \multicolumn{6}{|c|}{0.29} & \\
\hline
\end{tabular}

\section{Ascorbic acid content}

Data in Table 6 show that ascorbic acid content was increased with prolongation of storage period increased until 14 days of storage at $10^{\circ} \mathrm{C}$ and then was decreased till the end of storage period in both seasons. This increase might be due to the lower rate of sugar loss through respiration; however, the decrease in ascorbic acid might be due to the higher rate of sugar loss through respiration than water loss through transpiration (Willset al., 1998), these results are similar with those obtained by (Sakaldas and Kaynas, 2010).

Concerning the effect of postharvest treatments on ascorbic acid, data reveal that all treatments were effective on preventing ascorbic acid degradation during storage as compared with the untreated fruits (control), Moreover, in general active MAP at $5 \% \mathrm{O}_{2}$ $+10 \% \mathrm{CO}_{2}, \mathrm{Pppb}$ and $\mathrm{H}_{2} \mathrm{O}_{2}$ resulted in maintaining ascorbic acid content. Vapor gard treatment had slight effects on ascorbic acid preservation.

Modified atmosphere packages prevent ascorbic acid degradation caused by low $\mathrm{O}_{2}$ concentration it has been previously reported that in storage atmosphere of $\mathrm{O}_{2}$ the ascorbic acid level is preserve (Arvanitoyannis et al., 2005). Moreover, high $\mathrm{CO}_{2}$ treatment retarded the change in ascorbic acid content of pepper fruits during storage (Akbudak, 2008).

The increment of ascorbic acid content related to $\mathrm{H}_{2} \mathrm{O}_{2}$ treatments because it can be regenerated by two enzymes namely monodehydro ascorbate reductase and dehydro ascorbate reductase (Nishikawa et al., 2003) which could explain the increase by
$\mathrm{H}_{2} \mathrm{O}_{2}$ treatment during storage period. The stability of ascorbic acid directly increased in the presence of $\mathrm{H}_{2} \mathrm{O}_{2}$ during storage of orange and grape fruit juices (Ozkanet al., 2004).

As for the interaction between postharvest treatments and storage period, data in Table 6 show that sweet pepper treated with active MAP at $5 \% \mathrm{O}_{2}$ $+10 \% \quad \mathrm{CO}_{2}$ was the most effective treatment in reducing ascorbic acid loss at the end of storage.

\section{Total carotenoid (TC)}

Data in Table 7 show that total carotenoid contents in sweet pepper fruits were increased at the beginning of storage until 21 days of storage at $10^{\circ} \mathrm{C}$ and then decreased till the end of storage in both season. The increase in TC in the first period of storage may be due to the destruction of chlorophyll and accumulation of carotenoid, however, the decrease in TC at the last period of storage could be attributed to the gradually destruction by polyphenol oxidase enzymes (Mayer and Harel, 1991).

Concerning the effect of postharvest treatments on TC content, data show that, in general active MAP at $5 \% \mathrm{O}_{2}+10 \% \mathrm{CO}_{2}, \mathrm{Pppb}$ and $\mathrm{H}_{2} \mathrm{O}_{2}$ treatments resulted in maintaining $\mathrm{TC}$ contents during storage. These results were agreement with those obtained by $\operatorname{Akbudak}(2008)$ who found that changes in fruit color at the end of storage preceded more slowly in MAP treatment, however, the colors of untreated fruits, changed rapidly.

For the interaction between postharvest treatments and storage period on TC, data in Table 7 
reveal that sweet pepper fruits treated with active MAP and $\mathrm{H}_{2} \mathrm{O}_{2}$ were the most effective treatments in maintaining TC content at the end of storage. These results were true in both seasons.

\section{Conclusion}

Table 6. Effect of some postharvest treatments on ascorbic acid (mg/100g fresh weight) of sweet pepper fruits during storage at $10^{\circ} \mathrm{C}$ in $2010-2011$ and $2011-2012$ seasons.

\begin{tabular}{|c|c|c|c|c|c|c|c|c|c|c|c|c|}
\hline \multirow{3}{*}{ Treatments } & \multicolumn{6}{|c|}{ 2010/2011 seasons } & \multicolumn{6}{|c|}{ 2011/2012 seasons } \\
\hline & \multicolumn{5}{|c|}{ Storage period in days } & \multirow{2}{*}{ Mean } & \multicolumn{5}{|c|}{ Storage period in days } & \multirow{2}{*}{ Mean } \\
\hline & 0 & 7 & 14 & 21 & 28 & & 0 & 7 & 14 & 21 & 28 & \\
\hline $\begin{array}{l}\text { Active } \\
\text { MAP }\end{array}$ & 122.00 & 134.10 & 138.77 & 139.43 & 131.60 & 133.18 & 121.27 & 130.73 & 139.00 & 137.00 & 133.07 & 132.21 \\
\hline $\begin{array}{l}\text { Passive } \\
\text { MAP }\end{array}$ & 122.00 & 134.93 & 135.57 & 130.37 & 125.47 & 129.67 & 121.27 & 131.87 & 134.67 & 129.00 & 121.93 & 127.75 \\
\hline Pppb & 122.00 & 136.33 & 137.57 & 130.23 & 125.87 & 130.40 & 121.27 & 133.07 & 139.67 & 130.33 & 125.17 & 129.90 \\
\hline $\begin{array}{l}\text { Hydrogen } \\
\text { peroxide }\end{array}$ & 122.00 & 134.57 & 135.47 & 139.57 & 129.33 & 132.19 & 121.27 & 130.63 & 136.33 & 131.67 & 129.00 & 129.78 \\
\hline $\begin{array}{l}\text { Vapor } \\
\text { gard }\end{array}$ & 122.00 & 134.00 & 140.50 & 130.17 & 117.30 & 128.79 & 121.27 & 130.33 & 135.33 & 125.30 & 118.67 & 126.18 \\
\hline Control & 122.00 & 135.23 & 138.40 & 120.33 & 103.33 & 123.86 & 121.27 & 129.67 & 140.00 & 118.67 & 110.00 & 123.92 \\
\hline Mean & 122.00 & 134.86 & 137.71 & 131.68 & 122.15 & & 121.27 & 131.05 & 137.50 & 128.66 & 122.97 & \\
\hline \multicolumn{13}{|l|}{ L.S.D. at 5\% } \\
\hline \multicolumn{2}{|l|}{$\begin{array}{l}\text { Treatments }(\mathrm{T}) \\
\text { Storage period }\end{array}$} & \multicolumn{2}{|c|}{4.60} & & & \multicolumn{7}{|c|}{2.66} \\
\hline $\begin{array}{l}\text { Storage period } \\
\text { (S) }\end{array}$ & & \multicolumn{2}{|c|}{4.20} & & & \multicolumn{7}{|c|}{2.43} \\
\hline $\mathbf{T} \times \mathbf{S}$ & & \multicolumn{2}{|c|}{10.28} & & & \multicolumn{7}{|c|}{5.94} \\
\hline
\end{tabular}

Table 7. Effect of some postharvest treatments on carotenoids (mg/100g fresh weight) of sweet pepper fruitssduring storage at $10^{\circ} \mathrm{C}$ in $2010-2011$ and $2011-2012$ seasons.

\begin{tabular}{|c|c|c|c|c|c|c|c|c|c|c|c|c|}
\hline \multirow{3}{*}{ Treatments } & \multicolumn{6}{|c|}{$2010 / 2011$ seasons } & \multicolumn{6}{|c|}{ 2011/2012 seasons } \\
\hline & \multicolumn{5}{|c|}{ Storage period in days } & \multirow{2}{*}{ Mean } & \multicolumn{5}{|c|}{ Storage period in days } & \multirow{2}{*}{ Mean } \\
\hline & 0 & 7 & 14 & 21 & 28 & & 0 & 7 & 14 & 21 & 28 & \\
\hline Active MAP & 3.77 & 3.82 & 3.93 & 4.19 & 4.02 & 3.95 & 3.68 & 3.77 & 3.91 & 4.12 & 4.00 & 3.90 \\
\hline Passive MAP & 3.77 & 3.84 & 3.90 & 3.99 & 3.70 & 3.84 & 3.68 & 3.75 & 3.83 & 3.85 & 3.77 & 3.78 \\
\hline Pppb & 3.77 & 3.89 & 3.96 & 4.08 & 3.74 & 3.89 & 3.68 & 3.80 & 3.86 & 4.00 & 3.88 & 3.84 \\
\hline $\begin{array}{l}\text { Hydrogen } \\
\text { peroxide }\end{array}$ & 3.77 & 3.80 & 3.91 & 4.16 & 4.00 & 3.93 & 3.68 & 3.74 & 3.83 & 4.07 & 3.97 & 3.86 \\
\hline Vapor gard & 3.77 & 3.82 & 3.95 & 4.07 & 3.62 & 3.86 & 3.68 & 3.74 & 3.88 & 4.00 & 3.75 & 3.81 \\
\hline Control & 3.77 & 3.94 & 4.15 & 3.71 & 3.50 & 3.82 & 3.68 & 3.86 & 4.05 & 3.69 & 3.46 & 3.75 \\
\hline Mean & 3.77 & 3.85 & 3.97 & 4.03 & 3.76 & & 3.68 & 3.78 & 3.89 & 3.95 & 3.81 & \\
\hline \multicolumn{13}{|l|}{ L.S.D. at 5\% } \\
\hline Treatments (T) & & & 0.06 & & & & & & 0.07 & & & \\
\hline Storage period $(S)$ & & & 0.06 & & & & & & 0.07 & & & \\
\hline $\mathbf{T} \times \mathbf{S}$ & & & 0.14 & & & & & & 0.16 & & & \\
\hline
\end{tabular}

\section{References}

Abbott, J.A.(1999).Quality measurements of fruits and vegetable postharvest. Biol. Technol. 15: 207225.

Abd El-Rahman, S.Z.(1990). Physiological studies on development, handling and storage of pepper. Ph. D. Thesis Fac. Agric. Al-Azhar Univ., Egypt.

Akbudak, B.(2008).Effect of polypropylene and polyvinyl chloride plastic film packaging materials on the quality of 'yalovacharleston' pepper (Capsicum annuum L.) during storage. Food Sci. Technol. Res., 14 (1): 5-11.

A.O.A.C. (1990).Quality of Official Analytical Chemists, Washington DC. USA.
From the previous results it could be concluded that active MAP at $5 \% \mathrm{O}_{2}+10 \% \mathrm{CO}_{2}$ followed by $\mathrm{H}_{2} \mathrm{O}_{2}$ treatments is the promising technique for maintaining quality and extending the storage period of sweet pepper fruits. 
36pp. Volcani Centre, Bet Degan.

Bayoumi, Y.A.(2008). Improvement of postharvest keeping quality of white pepper fruits (Capsicum annuит, L.) by hydrogen peroxide treatment under storage conditions. Acta Biologica Szegediensis, 52: 7-15.

Ben-Yahoshua, S., B. Shapiro, Z.E. Chen, and S. Lurie (1983). Mode of action of plastic film in extending life of lemon and bell pepper fruits by alleviation of water stress. Plant Physiology, 73: 87-93.

Ceponis M.J., R.A. Cappelliniand R.A. Lightner(1987).Disorders in fresh pepper shipments to the New York market. Plant Dis, 71: 380-382.

Coates, L., T. Cooke, D. Persley, B. Beattie,N. Wade, and R. Ridgway(1995). Post-harvest of Horticultural Produce, Vol. 2, Tropical Fruits,Department of Primary Industries, Queen sland, Briesbane.

Collie Graddick, JR., F.M.Basiounyand M. Burns(1986).Effect of ethylene, metabolic, and transpiration inhibitors on prolonging the shelf-life of rabbiteye blueberry (Vacciniumashi Reade). Proc. Fla. State Hort. Soc., 99:203-205.

Conesa,A., B.E. Verlinden, F.Artes-Hernandez, B. Nicolai and F. Artes(2007). Respiration rates of fresh-cut bell peppers under super atmospheric and low oxygen with or without high carbon dioxide. Postharvest Biol. and Technol., 45: 81-88.

Davey, M.W., M. VanMontagu, D. Inzé, M. Sanmartin, A. Kanellis, N.Smirnoff, I.J.J. Benzie, J.J.Strain, D. Favell andJ. Fletcher(2000). Plant L-ascorbic acid: chemistry, function, metabolism, bioavailability and effects of processing. J Sci Food Agric., 80:825-860.

Desikan R, M. Cheung, J. Bright, D. Henson, J. Hancock, S. Neill(2004).ABA, hydrogen peroxide and nitric oxide signalling in stomatal guard cells. J Exp Bot 55:(395), Special Issue:205-212.

Du J., M. Fu, M. Li, W. Xia(2007). Effects of chlorine dioxide gas on postharvest physiology and storage quality of green bell pepper (Capsicumfrutescens L. var. Longrum). Agricultural Sciences in China, 6(2):214-219.

El-Sheikh,T.M., S.Z. Abd El-Rahman, andS.M.Hassanen(1997).Effect of calcium chloride and hydrated lime on keeping quality of sweet pepper and cucumber fruits. Annals Of Agric. Sci., Moshtohor, 35(4): 2371-2389.

Fallik, E., S. Grinberg, O. Yekutieli, A. Wiseblum, R. Regev, H.BeresandE. Bar-Lev(1999).A unique hot water treatment to improve storage quality of sweet pepper. Postharvest Biology and Technology, 15: 25-32.

Gonzalez-Aguilar, G.A., J.F. Ayala-Zavala, S. Ruiz-Cruz, E. AcedoFelix, and M.E. DiazCinco(2004).Effect of temperature and modified atmosphere packaging on overall quality of freshcut bell peppers.Lebens-Wissen und-Technol., 37:
817-826

Gonzalez-Aguilar,G.R. Cruz,R. Baez andC.Y. Wang(1999). Storage quality of bell peppers pretreated with hot water and polyethylene packaging. J Food Qual, 22 (3):287-299.

Gonzalez, G. and M. Tiznado (1993). Postharvest physiology of bell peppers stored in low density polyethylene bags. Lebensm.Wiss. U. Technol., 26: 450-455.

Hardenburg, R.E., A.E. WatadaandC.Y. Wang(1986). The commercial storage of fruits, vegetables and florist and nursery stocks.Pp, 2325, U.S. Dept. Agric. Handbook No. 66, Washington, DC.

Hardenburg, R.E., A. Watada andC.Y. Wang(1990).The commercial storage of fruits, vegetables, florist and nursey stocks. Washington, DC: US Department of Agriculture, Agriculture Handbook No. 66. pp. 23-25.

Jobling, J.(2001). Modified atmosphere packaging: Not as simple as it seems. Good Fruit and Vegetables Magazine 11: 1-3.

Lazan, H., Z.M. Ali and H.A. Sani(1990).Effect of vapor gard on polygalacturonase, malic enzyme and ripening of harumanis mango. Act Hort., 269: 359-366.

Lee, K.S.,K.L. Woo and D.S. Lee(2006a).Modified atmosphere packaging for green chili peppers.Packaging Technol. Sci., 7: 51-58.

Lee, L., J. Arul, R. Lencki and F. Castaigne(2006b). A review on modified atmosphere packaging and preservation of fresh fruits and vegetables: physiological basis and practical aspects-part I. Packaging Technol. Sci., 8: 315-331.

Le Lagadec, M.D. and M. Morudu(2002). Colouring up green skin mango cultivars.Merensky Technological Services, Mariepskop Estate, Private Bag X3009, Hoedspruit 1380, daniellel@ hansmerensky.co.za.

Lownds, N.K. and P.W. Bosland(1988).Studies on postharvest storage of pepper fruits.HortScience, 23(3): 71 (Abstr.).

Lurie, S., B. Shapiro andS. Ben-Yehoshua(1986). Effects of water stress and degree of ripeness on rate of senescence of harvested bell pepper fruit. J. Am. Soc. Hort. Sci., 111: 880- 885.

Maalekuu, K., Z. Elkind, S.Tuvia-Alkalai, Y. Shalom and E.Fallik(2003). Quality evaluation of three sweet pepper cultivars after prolonged storage. Adv. Hort. Sci., 17: 187-191.

Mayer, A.M. andE. Harel(1991).Polyphenoloxidase and their significance in fruit and vegetables.In P.F. Fox, ed., Food Enzymology, v.1, Elsevier, London, pp. 373-398.

Miller, W.R., L.A. RosseandR.E.McDonald (1986).Deterioration of individually wrapped and non-wrapped bell peppers during long term storage.Top. Sci., 26: 1-8.

Nawa,Y., H. Horita, K. Sato and T. 
Ishitani(2001).Quality preservation of fruits and vegetables by simple spotted cooling system and/or by packaging using new plastic films. JARQ., 35(2): 105-115.

Neill, S.J., R. Desikan, A. Clarke, R.D. Hurst and J. Hancock(2002).Hydrogen peroxide and nitric oxide as signalling molecules in plants. J Exp Bot, 53(372):1237-1247.

Nishikawa, F., M. Kato, H. Hyodo, Y.Ikoma, M. Sugiura andM. Yano(2003).Ascorbate metabolism in harvested broccoli. $\mathbf{J}$ Exp Bot,54:2439-2448.

NOP,(2003).National Organic Program, Federal Register / Vol. 68, No. 211 / Friday, October 31, 2003 / Rules and Regulations.

Nyanjage, M.O., S.P.O. Nyalala,A.O. Illa, B.W. Mugo, A.E.LimbeandE.M. Vulimu(2005).Extending post-harvest life of sweet pepper (Capsicum annuиm L. 'CaliforniaWonder') with modified atmosphere packaging and storage temperature.AgriculturaTropicaEtSubtropica, 38(2): 28-34.

Ozkan, M., A. Krca, andB. Cemeroglu(2004).Effects of hydrogen peroxide on the stability of ascorbic acid during storage in various fruit juices. Food Chem., 88(4):591-597.

Peng, L.T. and Y.M. Jiang(2003).Effects of chitosan coating on shelf life and quality of fresh-cut Chinese water chestnut.Lebensm. -Wiss. U. Technol. 36: 359-364.

Paull, R.E.(1990).Chilling injury of crops of tropical and subtropical origin. In: Wang C.Y. (ed.) chilling injury of horticultural crops. CRC Press, Boca Raton, FL. Pp. 17-36.

Sakaldas, M. andK. Kaynas(2010).Biochemical and quality changes of green sweet bell pepper as affected by different postharvest treatments. African J. of Biotech., 9(48): 8174-8181.

Saltveit, M.E. andA.R. Sharaf(1992). Ethanol inhibitors ripening of tomato fruit harvested at various degrees of ripeness without affecting subsequent quality. J Am Soc. Hort. Sci., 117:793798.

Sapers, G.M. and G.F. Simmons(1998).Hydrogen peroxide disinfections of minimally processed fruits and vegetables. Food Technol., 52(2) :48-52.

Sapers, G.M., R.L. Miller, V. Pilizota andF. Kamp(2001). Shelf life extension of fresh mushrooms (Agaricusbisporus) by application of hydrogen peroxide and browning inhibitors. J Food Sci., 66:362-366.

Shabana, H.R., M.S. Al-Khalid and N.D. Benjamin(1985).Effect of vapor gard and some preservatives on the quality of date fruits (Zahdi cv.) at rutab stage during cold storae. J. Agri. \& Water Resources. Research Center Sc., Baghdad, Iraq., 4(3): 207-220.

Shehata, S. A., M.I.A. Ibrahim, M.M. El-Mogyand K.F. Abd El-Gawad(2013). Effect of hot water dips and modified atmosphere packaging on extend the shelf life of bell pepper fruits. Wulfenia Journal, 20 (3): 315-328.

Simmons, G.E., J.L. Semilanick,S. John andD.A. Margosan(1997).Reduction of microbial populations on prunes by vapor phase hydrogen peroxide. J. Food Protect. 60, 188-191.

Snedecor, G.W. and W.G. Cochran(1980).Statistical Methods. $8^{\text {th }}$ Ed. Iowa State Univ. Press, Ames, Iowa, USA.

Thompson, A. K.(1996). Post-harvest Technology of Fruit s and Vegetables, Blackwell, Oxford.

Ukuku, D.O., M.L. Bari, S. Kawamoto andK. Isshiki(2005). Use of hydrogen peroxide in combination with nisin, sodium lactate and citric acid for reducing transfer of bacterial pathogens from whole melon surfaces to fresh-cut pieces. Int. J. Food Microbiol., 104: 225-233.

Wang, C.Y. andL. Qi(1997). Modified atmosphere package alleviates chilling injury in cucumbers. Postharvest Biology and Technology, 10: 195-200.

Wills, R., B. Mcglasson, D. Graham, andD. joyce(1998). Post-harvest: An Introduction to the Physiology and Handling of fruit, Vegetables and Ornamentals. Ed.: CAB International, Wallingford, UK.

Xie, M.H., J.M. Zhu and J.M,Xie(2004). Effect factors on storage of green pepper. J Gansu Agric Univ.,3:300-305. 


\section{تأثير بعض معاملات ما بعد الحصاد على صفات الجوده لثمار القلقل الحلو خلال التخزين المبرد}

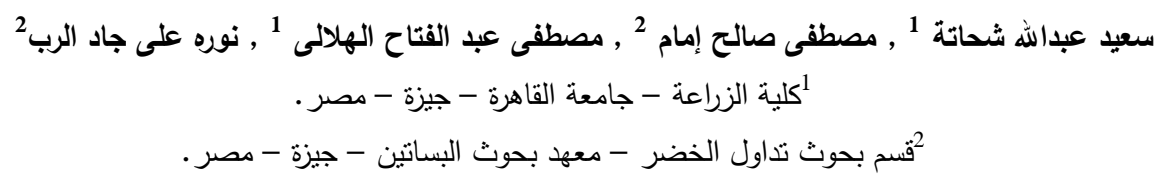

أجريت الدراسة على هجين الفلفل الحلو (مونست) حيث تم جمع الثمار فى مرحلة 4/3 نلوين (أصفر) من مزرعة خاصة بمركز فايد

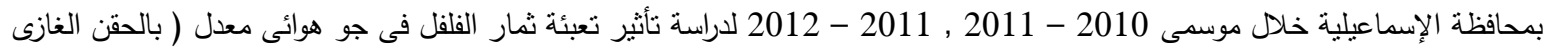

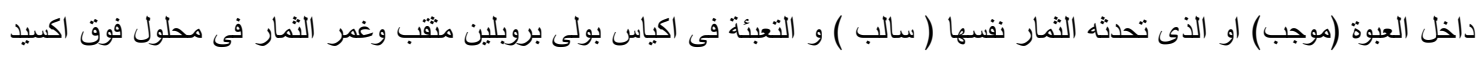

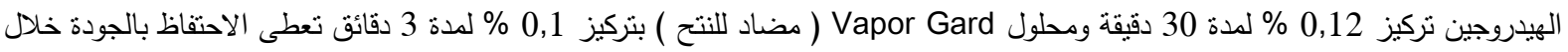

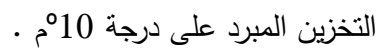

وقد أوضحت النتائج ان كل المعاملات المستخدمة قد أدت الى تقليل فقد الوزن والنالف وفقد الصلابة والتغير فى اللون مقارنة بالثمار

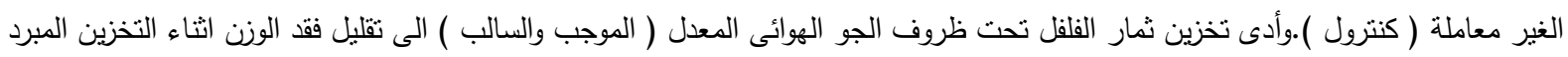

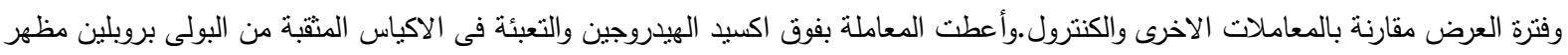

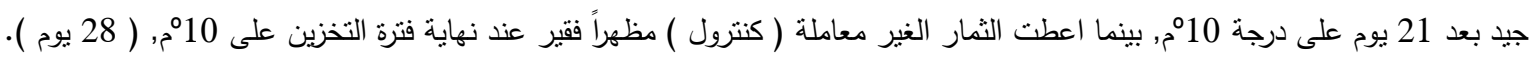

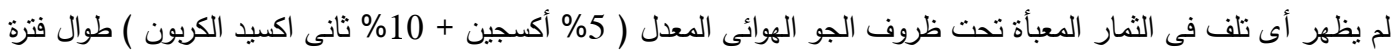

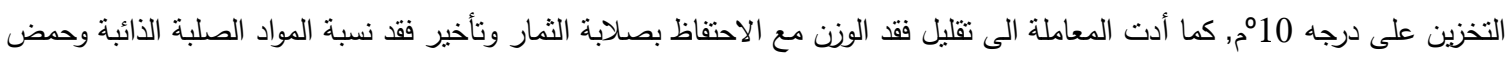

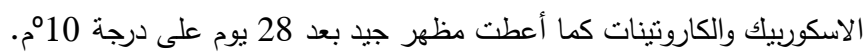

لذا يمكن اعتبار تعبئة ثمار الفلفل تحت ظروف الجو الهوائى المعدل (الموجب ) يليها المعاملة بفوق اكسيد الهيدروجين طريقة واعده فى المحافظة على صفات الجودة واطالة فترة حياة الثمار طوال فترة التخزين.

مشروع تطوير معاملات ما بعد الحصاد للمحاصيل التصديرية 